\title{
The Correlation Between Reading Achievement and Writing Achievement to the Eight Graders of Bilingual Class At SMP Negeri 1 Palembang
}

\author{
by \\ Arief Pamuji*) \\ English Lecturer of STIK Bina Husada \\ Palembang \\ arief black85@ymail.com
}

\begin{abstract}
The objective of this research was to find out whether or not there is a correlation between reading achievement and writing achievement. The sample of this research was taken by using purposive sampling with total 36 students of the bilingual class in eighth grade students of SMP Negeri 1 Palembang in the academic year 2007/2008. The data were obtained by using reading comprehension test and writing test. To verify the hypotheses, the primary data were analyzed by using correlation and regression analyses by means of Statistical Product and Service Solution (SPSS) version 12.00 computer program. Based on the data analysis, the correlation coefficient $\left(\mathrm{r}_{\mathrm{xy}}\right)$ was 0.614 at the significance level $p<0.05$ in two tailed. Since the value of $r$ obtained was higher than the critical value of $r$-table $(0.614>0.3291)$, the null hypothesis (Ho) was rejected and consequently, the research hypothesis $\left(\mathrm{H}_{1}\right)$ was accepted. This shows a significant correlation between the reading Achievement and the writing Achievement to the eighth graders of bilingual class at SMP Negeri 1 Palembang. Based on the regression analysis, it was found that students' reading achievement determined or influenced $37.7 \%$ of their writing achievement and the rest $(62.3 \%)$ was defined by other factors. It means that there was a significant influence of reading achievement on the students' writing achievement.
\end{abstract}

Key words: reading achievement and writing achievement

Nowadays, the government is trying to improve the quality of education in Indonesia. Our quality of education was lower than other countries, like Malaysia or Singapore. They have made progress in education for the past decade. So, Indonesian government tries to improve the quality of education in order to be competitive in the global era.

In Indonesia, according to the curriculum, one of the important things that the government is trying hard to improve is English Competence. It is obvious that English is very important for people to have a good position in the company or other areas. Besides its use for communication among nations, English is also used as a prominent language of science in all the textbooks of kinds of field, such as, mathematic, science, and social studies. So, now we can find the English language in many kinds of textbook. Since English is very important in Indonesia it is introduced as a compulsory subject to secondary and high school students, and nowadays as a local content for junior high school and elementary school. To improve the educational quality some schools applying bilingual class for their students. "Bilingual education is the use of two languages, one of which is English, as a medium of instruction for the same pupil population in a well- 
organized program that encompasses part or of all the curriculum arid includes the study of the history and culture associated with the mother tongue" (Akkari1998:8). In the bilingual class, the students are taught by using two languages. The first is mother tongue, that is our language or Indonesian language and the seconds is second language or English language. From the survey to the SMP 1 who taught bilingual class, the writer got information that in bilingual class, the teacher taught about 95 percent by using English language and the rest is using Indonesian language.

In learning English or language as a foreign language, it means we are trying to master four language skills, namely, listening, speaking, reading and writing. Listening skill is aimed at understanding the spoken language. In listening skill the students are taught to understand the conversation or talk using English. In speaking skill the students use language orally when they speak to each other, in speaking skill the students can understand how to speak well and clearly. Reading skill refers to understanding the ideas of written language. In reading the students are taught to comprehend texts by looking at the aspects in reading and to understand the text in their mind. And the last one of the language skill, writing skill is expressing ideas in a written form. The students are taught to increase their skill and to express their feeling in writing something and to understand how to write well with the aspect of writing, for example grammar, vocabulary, content, mechanics and organization. Four skills in language are important because a lot of scientific book are written in English. In order to understand those books the students must have good reading skill. "Besides, a person learn English because they want to be able to communicate with other by using the language, and one of the most important ways to communicate with speakers of other languages and with members of other cultures is via reading" (Feurstein and Scholnik, 1995).

Anderson (1985: 8, cited in Rubin, 1997: 3) states reading is a process in which information from the text and the knowledge possessed by the reader act together to produce meaning. Ruddel (1993:21) support the statement, by stating that reading is the act of constructing meaning while interacting with the text, just as we use information stored in schemata to understand and interact with the world around us.

Writing is considered as the most different one for students to learn (Valette, 1977:217). He points out that "of the four skills, writing may truly be considered as the most sophisticated".

From the statements above, sometimes some students has some difficult in writing, and cannot write well because of some reasons. Perhaps they didn't know how to construct the sentences correctly or they didn't felt confident themselves to write because they think that writing is hard for them.

According to the Bazerman (1980:656), the connection between what a person reads and what the person then writes seems so obvious as to be realistic. On the other hand, Parody (2007:225-250), states that "reading and writing are both language processes, one can assume relationships between them, but the exact nature of these relationships has not yet been determined". While a large body of research has addressed reading comprehension and written production independently, there are very little investigation has examined the possible 
relationships between these two psycholinguistic processes. White (1985. 100119) states that current theory supports the latter, that reading is a process of interaction between reader and text. Also currently popular are theories of writing as a process, and measurement of writing using holistic scoring. Author ties these trends together.

The writer believes that from reading achievement the students can influence their writing achievement or from the writing they can influence their reading achievement. Because both of them has similar aspect and has related to each other.

Based on the outline above, the problems of this study were formulated in the following questions: Is there any correlation between reading achievement and writing achievement to the eighth graders of bilingual class at SMP Negeri 1 Palembang.

And the objectives of this study were to find out whether or not there is any correlation between reading achievement and writing achievement.

\section{METHOD OF THE RESEARCH}

The researcher uses correlation study in conducting the research. In this study the researcher would like to find out the correlation between reading achievement and writing achievement of the eight graders of bilingual class at SMP Negeri 1 Palembang. The population of this research is all the bilingual class in eighthgrade students of SMP Negeri 1 Palembang in academic year 2007/2008 with total 72 . in this study. The study sample was 36 from total of the population by using purposive sampling technique.

The study was conducted by using reading achievement test and writing achievement test which related to the variables of the study.

There are two possible results of this correlational study; there is correlation and there is no correlation. The correlation coefficient is a measure of correlation strength and can range from -1.00 to +1.00

\section{Technique for Collecting and Analyzing the Data}

Brown (1991:2) states that test is a method of measuring a person ability of knowledge in a given area. From the statement of Brown, in collecting the data the researcher used two tests to collect the data in the study, there are reading comprehension test and writing test

Reading Test, The researcher gave reading test, in order to measure the student's achievement. In the test the writer gave the student several texts. It consist of 60 multiple choice items from six reading passages taken from some sources that's containing the literal comprehension (Main idea, detailed, vocabulary, referent, inference, and text organization). The researcher did the try out test to find the validity. From the test the writer found only 40 valid items that would be applied to the real test in SMP N 1 Palembang. 
Writing test, after giving reading test the reseacher asked the student to write an essay that they chose from three topics. They must create their paragraphs based on their knowledge of writing good paragraphs.

In this study the researcher asked two raters to assess the student's writing. The writer asked the lectures from English major of Sriwijaya University to find the scoring of the student's writing. The raters give the students' score based on a modified banded marking scheme. The researcher also would like to determine the students' level of achievement in reading and writing. In this case, researcher used the criterion-referenced grading system. It is a system of grading which is based on absolute level of achievement (Tinambuan, 1988:128, cited in Wahyuni 2002: 16).

\section{FINDINGS AND INTERPRETATION}

\section{Findings}

From the analyzing the data, the study found the important things.

First, the study showed that the lowest score in the reading comprehension test was 58, and the highest score was 95 . And the reading level category showed that $5(13.88 \%)$ students were in outstanding level, $11(30.55 \%)$ students were in very good level, $14(38.88 \%)$ students were in satisfactory level, $4(11.11 \%)$ students were in very weak level, and $2(5.55 \%)$ students were in fail level. (see chart 1)

\section{Chart 1.}

The Score Distribution of the Reading Comprehension Test

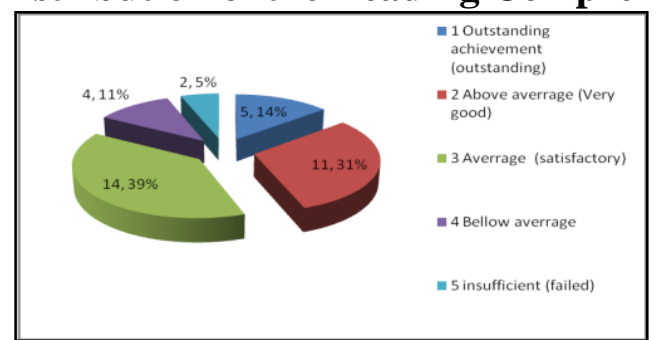

Second, the result showed that The lowest score in the Writing test was 53, and the highest score was 97. And from the category level found that 7 (19.44\%) students were in outstanding level, $4(11.11 \%)$ students were in very good level, $8(22.22 \%)$ students were in satisfactory level, $16(44.44 \%)$ students were in very weak level, and 1 (2.77\%) students were in fail level. (see chart 2)

\section{Chart 2.}

The Score Distribution of the Writing Test

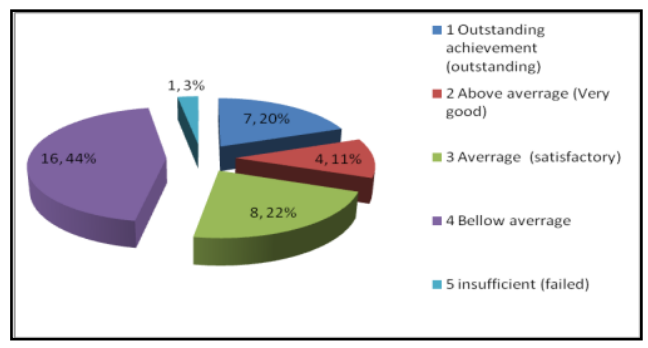


Third, based on the results of pearson product moment analysis, the researcher was found that there was a significant correlation between the reading achievement and the writing achievement to the eighth grade students of SMP Negeri 1 Palembang. The correlation coefficient $\left(\mathrm{r}_{\mathrm{xy}}\right)$ was 0.614 at the significance level $p<0.05$ in two tailed testing with $\mathrm{df}=34$, the critical value of $r$-table is 0.3291 . Since the value of $r$-obtained was higher than the critical value of $r$-table $(0.614>0.3291)$, the null hypothesis (Ho) was rejected and consequently, the research hypothesis $\left(\mathrm{H}_{1}\right)$ was accepted. (see table 1)

The regression analysis was applied to determine whether the students' reading achievement influenced or determined their writing achievement. The findings showed that the t-obtained was 4.537 and it exceeded the critical value of t-table 1.688, so reading achievement of students influenced their writing achievement. The contribution of reading achievement to writing achievement can be seen by the score of $\mathrm{R}^{2}$ (the coefficient determiner) which was 0.377 . It means that reading achievement influenced writing achievement for about $37.7 \%$, and $62.3 \%$ of this value was defined by other factors. (see table 2)

Table 1

The Correlation between reading and writing achievements

\begin{tabular}{|l|l|r|r|}
\hline & & Reading & \multicolumn{1}{c|}{ Writing } \\
\hline Reading & Pearson Correlation & 1 & $.614(* *)$ \\
& Sig. (2-tailed) &. & .000 \\
\multirow{4}{*}{ Writing } & $\mathrm{N}$ & 36 & 36 \\
& Pearson Correlation & $.614(* *)$ & 1 \\
& Sig. (2-tailed) & .000 &. \\
& $\mathrm{~N}$ & 36 & 36 \\
\hline
\end{tabular}

** Correlation is significant at the 0.01 level (2-tailed).

Table 2

Statistics Summary for Predicting Writing Achievement from Reading Achievement

\begin{tabular}{|l|c|l|c|c|c|c|c|c|c|}
\hline Model & $\begin{array}{c}\text { Dependent } \\
\text { Variable }\end{array}$ & $\begin{array}{c}\text { Independent } \\
\text { Variable }\end{array}$ & $\mathrm{R}$ & $\mathrm{R}^{2}$ & $\mathrm{df}$ & $\mathrm{t}$ & sig & Stand.Beta & $\begin{array}{c}\text { Unstand } \\
\text { Beta }\end{array}$ \\
\hline 1 & Writing & Reading & 0.614 & 0.377 & 34 & 4,537 & .000 & 0.614 & 0,801 \\
\hline
\end{tabular}

\section{Discussion}

Based on the result of the research, it was found that there is a correlation between reading achievement and writing achievement to the eighth graders of bilingual class at SMP Negeri 1 Palembang because the correlation coefficient was 0.614. According to Gleason (1995:91) reading and writing influence each other. He also states, when researchers examined students' writing experiences, they found that students' writings increased their comprehension of reading passages, which led them to use more complicated structures in their writings.

The results of this research also support the above-mentioned statements. The coefficient of determination $\left(\mathrm{r}^{2}\right)$ of reading achievement and writing achievement is 0.377 . It means that reading achievement influenced writing achievement for 
about $37.7 \%$. The results show that the process of students in learning reading to have good reading skill, the students has the opportunity to become good writers. De Ford's (1981:657), his observations of first graders indicate that "there is a supportive, interactive relationship between the reading and writing processes. Children learn about how to become writers from reading as well as how to become readers. So, the students' reading achievement has good positive impact to their writing achievement

\section{CONCLUSION AND SUGGESTION}

\section{Conclusion}

In this research the researcher point out to find the correlation among attitude toward English, reading comprehension, and writing achievement. In this research, students' attitude toward English gives positive significant correlation on their reading comprehension achievement, and writing achievement. furthermore, based on the results of pearson product moment analysis, it was found that students' attitude toward English had a positive significant correlation with their reading comprehension. Then, the correlation between the students' attitude toward English and their writing achievement also found positive and significant. Additionally, it also found that there was also a positive significant correlation between two dependent variables (reading comprehension and writing achievement). And, the researcher concluded that there was a correlation among students' attitude toward English, reading comprehension achievement, and writing achievement. The correlation was medium or sufficient. It means that the students who got good in attitude test tended to get good scores in the reading comprehension, and writing test. The students who got low scores in attitude test tended to get low scores in the reading comprehension, and writing test.

From the result of regression analysis, the researcher showed that attitude toward English influence reading, and writing achievement for about $29.0 \%$ where the highest contribution from three sub-scales of attitude factor was attitude toward English learning. This finding means that the students' reading comprehension and writing were determined by other factors. Furthermore, the reading comprehension level which was contributed by attitude toward English showed that the vocabulary level as the highest contributed by attitude, and also the writing elements which was contributed by attitude toward English showed that the vocabulary element as the highest contributed by attitude.

Finally, learning a new language is linked to the way in which the learner views the target language community and culture. Gardner (2003, p. 23) insists that students' attitude towards the target language group will affect their success in learning that language. Normally, learners manifest different attitude towards the target language, target language speaker, the target language culture, and social value of learning the second language, particular uses of the target language , and them selves as members of their own culture.

\section{Suggestions}


Having conducted this study, the writer suggests parents, teachers, other researchers and government to do as follows:

First, Being proficient in English doesn't happen instantly. It should be developed through a process of routing habit. It is suggested that parents could help their children in learning English; it can be done by providing their children books, film, or other materials in English. By dong so, it is hoped that the children will have positive attitude in learning English

Second, teachers are suggested to use various techniques in teaching English so that they can cover the students' individual differences especially in terms of attitude, reading comprehension, and writing.

Third, for the next researchers, it is suggested to do another research dealing with this topic. Doing another correlation study related to the English attitude, reading comprehension, and writing achievement will be interesting, for example by trying to find out the relationship among gender, reading, and writing.

Four, hopefully, the government will give more chances to use of attitude theories in terms of classroom activities, class size, and assessment. Government also hoped to provide the English access in order to motivate the students in learning English, so that Indonesian students can competence to the world.

\section{REFERENCES}

Anderson, R. C., Spiro, R. J. \& Montague, W. E. (1977). Schooling and the Acquisition of Knowledge. Hillsdale, NJ: Erlbaum. http://cela.albany.edu/emalius.hatm Accessed on November, $4^{\text {th }} 2007$

Akkari, Abdeljalil.(1998). Bilingual Education: Beyond Linguistic Instrumentalization.

Spring. MA.

http://www.bedfordstmartins.com/basicbib/contet/pi.ru.html Accessed on January, $24^{\text {th }}, 2008$

Bazerman, Charles. (1980). Relationship between Reading and Writing: The

Conventional Model. College English, Vol. 41. No.6

http://links.jstor.org/sci? Accessed on November, $4^{\text {th }} 2007$

Baker, Colin. (2001). Foundations of Bilingual Education and Bilingualism $3^{\text {rd }}$ edition. Buffalo, NY. Multilingual Matters, LTD.

Bissex, G. L. (1980). GNYS AT WRK: A child learns to write and read. Cambridge, MA: Harvard University Press. http://links.jstor.org/sci? Accessed on November, $4^{\text {th }} 2007$ 
Block, Cathy C. (1993). Teaching the Language Arts. Expanding thinking through student centred instruction. Lexington. MA. Allyn and Bacon. Icn.

Brown, Karen D'angelo. (1991). Language Arts: Exploring Connection. NY: Allyn and Bacon.

Carlin, Debra. (1997). Definition of Reading. Houghton Mifflin Company. http://www.siu.edu.com (Sep 20, 2007)

Cheek, Earl H., Rona F. Flipo, and Jimmy D Lindsey. (1989). Reading For Success in Elementary School. Boston, MA : Holt, Rinehart and Winslon, Inc

Choale, Joyce S and Thomas R. Rakes. (1993). The Successful Mainstreaming, Proven Ways to Detect and Correct Special Needs. Nedham Heights, Massachossetts: Ally and Bacon.

Clément, R. (1980). Ethnicity, contact and communicative competence in a second. language. In H. Giles, W. P. Robinson, \& P. M. Smith (eds.), Language: Social

Psychological Perspectives. Oxford: Pergamon, pp. 147-154.

DeFord, D. E. (1981). Literacy: Reading, Writing, and Other Essentials. Language Arts, 58(6), 652-658.

Eanes, Robin. (1997). Content Area Literacy (Teaching For Today and Tomorrow). New York, NY : Delmar Publisher.

Feurstein, Tamar and Miriam Scholnik. (1995). Enhancing Reading Comprehension in the Language Learning Classroom. NY: Alta Book Center.

Gardner, H. (2003). Frames of mind. The theory of multiple intelligences. New York: BasicBooks.

Gleason, M. M. (1995). "Using direct instruction to integrate reading and writing for students with learning disabilities". Published in Reading \& Writing Quarterly: Overcoming Learning Disabilities, 11, 91-108. http://www.cpt.fsu.edu/TREE/gleas95.html Accessed on November $13^{\text {rd }}$, 2007

Hedge, Tricia. (1988). Writing. $5^{\text {th }}$ ed. Oxford: University Press

Hill, Walter R. (1979). Secondary School Reading Process, Program, Procedure. Boston, MA: Allyn and Bacon. 
Ishak, Ismail. (2005). Improving EFL Students' Reading Speed and Their reading Comprehension by Using A Computer Reading Program. Unpublished Magisterial Theis. Faculty of Teacher Training and Education Sriwijaya University. Palembang

Kieft, Marleen; Rijlaarsdam, Gert; Galbraith, David; van den Bergh, Huub. The Effects of Adapting a Writing Course to Students' Writing Strategies. British Journal of Educational Psychology, v77 n3 p565-578 Sep 2007. http://ww.eric.ed.gov/ERICWEBPORTAL/Home.portal Accessed on November, $4^{\text {th }}, 2007$

Langer, J. A. (1986a). Children Reading and Writing: Structures and Strategies. Norwood, NJ: Ablex.

Levine, M. (2002). Difficulties with writing. WGBH Educational Foundation. http://www.pbs.org/wgbh/missunderstoodminds/writingdiffs.html. Accessed on September 12 2007.

Leipzig, D. H. (2001). What is reading? WETA. www.indiana.edu/ cwp/lib/readbib.shtml Accessed on March, $10^{\text {th }} 2008$

Parodi, Giovani. (2007). Reading-Writing connections: Discourse-Oriented Research. Reading and Writing: An Interdisciplinary journal . http://www.eric.ed.gov/ERICWebPortal/Home.portal Accessed on November, $4^{\text {th }} 2007$

Rubin, Dorothy.(1983).Teaching Reading and Study Skill in Content Areas. Boston, MA: A Division of Simon and Schuster. Inc.

Rubin, Dorothy. (1997). Diagnosis and Correction. Needham Heights; MA: Allyn and Bacon

Ruddell M. R. (1993). Teaching content reading and writing. Boston: Allyn and Bacon

Saunders. (1982). Bilingual education: Beyond linguistic instrumentalization. Spring. MA

Tierney, R. J. (1992). Ongoing Research and New Directions. In J. W Irwin \& M. A. Doyle (Eds.), Reading/Writing Connections Learning from Research (pp. 246-259). Newark: International Reading Association.

Valette, Rebecca M. (1997). Modern Language Testing. Boston, MA : Harcourt Brace Javanovich . 
Wahyuni, Wiwik. (2002). The Correlation Between Reading Ability and Spelling Ability. Unpublished Undergraduate Thesis. Faculty of Teacher Training and Education, Sriwijaya University, Indralaya.

White, Edward H. "How Theories of Reading Affect Responses to Student Writing." Teaching and Assessing Writing.

www.indiana.edu/ cwp/lib/readbib.shtml Accessed on October, $30^{\text {th }} 2007$

Winkler, Anthony C. (1987). Re-Writing Writing Rhetoric. 